\title{
Poly-gamma Glutamic Acid
}

National Cancer Institute

\section{Source}

National Cancer Institute. Poly-gamma Glutamic Acid. NCI Thesaurus. Code C106124.

A water-soluble and biodeg radable polymer naturally synthesized by various strains of Bacillus and composed of D- and L-glutamic acid polymerized via gamma-amide linkages, with potential antineoplastic activity. Upon administration, poly-gamma glutamic acid may augment the immune response by increasing the production of interferongamma (IFN-gamma) and tumor necrosis factor-alpha (TNF-alpha) and inducing the activation of macrophage and natural killer (NK) cells. IFN-gamma is a major mediator of innate and adaptive immunity against viral and intracellular bacterial infections as well as for tumor control. TNF-alpha is a cytokine involved in systemic inflammation, which is capable of inducing apoptotic cell death and exhibits anti-tumoral effects. 